\title{
Dukungan Sosial Orangtua, Regulasi Diri dan Prokrastinasi Akademik pada Siswa SMK Farmasi Depok
}

\author{
Dela Atfilah \\ Universitas Gunadarma \\ Email: delatfilah@gmail.com
}

\begin{abstract}
This study aims to examine: (1) the influence between social support of parents and academic procrastination of Depok Pharmacy Vocational students, (2) the influence between self-regulation and academic procrastination on Depok Pharmacy Vocational students, and (3) the influence between social support of people old, self-regulation with academic procrastination. This study uses a correlational quantitative method. There are three scales used in this study, namely the scale of parental social support, the scale of self-regulation, and the scale of academic procrastination. Researchers used as many as 80 students of Depok Pharmacy Vocational School as a study sample selected using saturated sampling techniques. The data analysis technique used in this study is multiple linear regression test. The results of this study indicate that: (1) parental social support has a significant influence on academic procrastination with a negative relationship direction which can be seen from the significance value of 0,000 and the regression coefficient of -0.173 . (2) self-regulation has a significant effect on academic procrastination with a negative relationship direction which can be seen from the significance value of 0,000 and the regression coefficient of $-0,627$. (3) Rsquare value of 0,481 ; it means that $48.1 \%$ of the variation in academic procrastination is influenced by parental social support and self-regulation, the remaining $51.9 \%$ is caused by other variables not measured in this study. The relationship between social support of parents and self-regulation with academic procrastination is known to have a significant relationship with a significance value of 0,000 .
\end{abstract}

Keywords: Parental social support, self regulation, academic procrastination

\begin{abstract}
Abstrak
Penelitian ini bertujuan untuk menguji: (1) pengaruh antara dukungan sosial orang tua dan prokrastinasi akademik siswa SMK Farmasi Depok, (2) pengaruh antara regulasi diri dan prokrastinasi akademik pada siswa SMK Farmasi Depok, dan (3) pengaruh antara dukungan sosial orang tua, regulasi diri dengan prokrastinasi akademik. Penelitian ini menggunakan metode kuantitatif korelasional. Terdapat tiga skala yang digunakan dalam penelitian ini, yakni skala dukungan sosial orang tua, skala regulasi diri, dan skala prokrastinasi akademik. Peneliti menggunakan sebanyak 80 siswa SMK Farmasi Depok sebagai sampel penelitian yang dipilih dengan menggunakan teknik sampling jenuh. Teknik analisis data yang digunakan dalam penelitian ini ialah uji regresi linier berganda. Hasil penelitian ini menunjukkan bahwa: (1) dukungan sosial orang tua memiliki pengaruh yang signifikan dengan prokrastinasi akademik dengan arah hubungan yang negatif yang dapat dilihat dari nilai signifikansi sebesar 0.000 dan koefisien regresi -0.173. (2) regulasi diri memiliki pengaruh yang signifikan dengan prokrastinasi akademik dengan arah hubungan yang negatif yang dapat dilihat dari nilai signifikansi sebesar 0.000 dan koefisien regresi -0.627 . (3) nilai $\mathrm{R}_{\text {square }}$ sebesar 0.481 ; artinya sebesar $48.1 \%$ variasi pada prokrastinasi akademik dipengaruhi oleh dukungan sosial orang tua dan regulasi diri, sisanya sebesar 51.9\% disebabkan oleh variabel lain yang tidak diukur dalam penelitian ini. Hubungan antara dukungan sosial orang tua dan regulasi diri dengan prokrastinasi akademik diketahui memiliki hubungan yang signifikan dengan nilai signifikansi sebesar 0.000 .
\end{abstract}

Kata kunci: Dukungan sosial orang tua, Regulasi diri, Prokrastinasi akademik.

\section{Pendahuluan}

Pendidikan mempunyai peranan penting bagi kelangsungan kehidupan manusia. Pendidikan menurut UU No. 22 Tahun 2003 tentang Sistem Pendidikan Nasional, adalah usaha sadar dan terencana untuk mewujudkan suasana belajar dan proses pembelajaran agar peserta didik secara aktif mengembangkan potensi dirinya untuk memiliki kekuatan spiritual, keagamaan, pengendalian diri, kecerdasan akhlak mulia serta keterampilan yang diperlukan dirinya, masyarakat, bangsa dan Negara (Puspitasari, 2012). Siswa sebagai subjek dalam pendidikan hendaknya mampu bertanggungjawab atas kewajibannya sebagai seorang pelajar, yang mana tugas utama seorang siswa adalah belajar. Namun pada kenyataannya masih banyak siswa yang mengabaikan kewajibannya. Misalnya, masih banyak siswa yang datang terlambat ke sekolah, kurangnya motivasi dalam belajar, tidak mengerjakan PR, melanggar tata tertib, norma dan lain sebagainya (Musyarofah, 2017).

Usia SMK merupakan anak usia remaja yang mana dalam pergaulan mereka masih mudah terpengaruh dengan lingkungan luar dan penasaran dengan hal-hal yang baru. Hal ini sesuai dengan teori psikologi yang menyebutkan bahwa rentangan usia remaja berada dalam usia 12 sampai 21 tahun bagi wanita, dan 13 sampai 22 bagi pria (Mappiare, 1982). Secara psikologis, masa remaja 


\author{
Dela Atfilah \\ Psyche 165 Journal Vol 14 No 1 (2021) 1 - 7
}

adalah usia dimana individu berinteraksi dengan masyarakat dewasa, usia dimana anak tidak lagi merasa di bawah tingkat orang-orang yang lebih tua melainkan berada dalam tingkat yang sama, sekurang-kurangnya dalam masalah hak. Integrasi dalam masyarakat (dewasa) mempunyai banyak aspek efektif, kurang lebih berhubungan dengan masa puber. Termasuk juga perubahan intelektual yang mencolok. Transformasi intelektual yang khas dari cara berfikir remaja ini memungkinkannya untuk mencapai integrasi dalam hubungan sosial orang dewasa, yang kenyataannya merupakan ciri khas yang umum dari periode perkembangan remaja (Hurlock, 2003).

Studi pendahuluan yang dilakukan peneliti di SMK Farmasi depok menemukan bahwa masih banyaknya siswa yang melakukan penundaan tugas akademik atau dalam istilah psikologi dikenal dengan istilah prokrastinasi akademik.

Istilah prokrastinasi berasal dari bahasa Latin procrastination dengan awalan pro yang berarti mendorong maju atau bergerak maju dan akhiran -crastinus- yang berarti keputusan hari esok, atau jika digabungkan menjadi menangguhkan atau menunda sampai hari berikutnya (Steel, 2007). American College Dictionary menjelaskan tentang prokrastinasi sebagai menangguhkan suatu tindakan untuk melaksanakan suatu tugas yang akan dilaksanakan pada waktu atau hari lainnya (Ardina dan Wulan, 2016). McCloskey (2011) mendefinisikan prokrastinasi akademik sebagai sebuah kecenderungan untuk menunda kegiatan dan perilaku yang terkait dengan pendidikan. Milgram, Batori dan Mowrer mendefinisikan prokrastinasi akademik merupakan sebuah tendensi untuk menunda atau menghindari pekerjaan atau tugas sekolah dan belajar (Pychyl, 2000).

Beberapa hasil penelitian menunjukkan bahwa prokrastinasi merupakan salah satu masalah yang menimpa sebagian besar anggota masyarakat secara luas, dan pelajar pada lingkungan yang lebih kecil, seperti sebagian pelajar di sana. Sekitar $25 \%$ sampai dengan $75 \%$ dari pelajar melaporkan bahwa prokrastinasi merupakan salah satu masalah dalam lingkup akademis mereka (Ferrari, Keane, Wolf, \& Beck, 1998 dalam Muhid, 2009) Solomon and Rothblum (dalam Balkis, 2013) menemukan bahwa $46 \%$ pelajar melakukan prokrastinasi pada tugas-tugas akademik, sekurang-kurangnya setengah dari waktu mereka.

Menurut Ferrari, 1995 (dalam Saraswati, 2017) faktor-faktor yang mempengaruhi prokrastinasi akademik dapat dikategorikan dua macam, yaitu faktor internal dan faktor eksternal. Salah satu faktor eksternal antara lain adanya dukungan sosial. Menurut Canavan \& Dolan (dalam Tarmidi dan Rambe, 2010), dukungan sosial dapat diaplikasikan ke dalam lingkungan keluarga, seperti orang tua. Jadi dukungan sosial orang tua adalah dukungan yang diberikan oleh orang tua kepada anaknya baik secara emosional, penghargaan, instrumental, informasi ataupun kelompok. Dukungan orangtua merupakan sistem dukungan sosial yang terpenting di masa remaja. Dibandingkan dengan sistem dukungan sosial lainnya, dukungan orangtua berhubungan dengan kesuksesan akademis remaja, gambaran diri yang positif, harga diri, percaya diri, motivasi dan kesehatan mental. Keterlibatan orangtua dihubungkan dengan prestasi sekolah dan emosional serta penyesuaian selama sekolah pada remaja. Menurut Lee \& Detels (2007), dukungan sosial orangtua dapat dibagi menjadi dua hal, yaitu dukungan yang bersifat positif dan dukungan yang bersifat negatif. Dukungan positif adalah perilaku positif yang ditunjukkan oleh orangtua, dan dukungan yang bersifat negatif adalah perilaku yang dinilai negatif yang dapat mengarahkan pada perilaku negatif anak. Selain itu faktor kepribadian yang dapat mempengaruhi perilaku prokrastinasi akademik yaitu regulasi diri. Regulasi diri merupakan salah satu faktor internal dari perilaku prokrastinasi. Regulasi diri adalah kemampuan untuk merencanakan, mengarahkan, dan memonitor perilaku untuk mencapai suatu tujuan tertentu dengan melibatkan unsur fisik, kognitif, emosional, dan sosial (Brown, dalam Fitriya dan Lukmawati, 2016). Zimmerman (dalam Fitriya dan Lukmawati , 2016), menjelaskan bahwa seseorang disebut memiliki regulasi diri jika pikiran dan perilakunya berada di bawah kendalinya sendiri, tidak dikendalikan oleh orang lain dan lingkungan.Berbagai hasil penelitian sebelumnya juga menggambarkan pentingnya regulasi diri dalam belajar karena berkorelasi dengan usaha belajar yang efektif dan efisien. Berdasarkan penelitian Fitriya dan Lukmawati (2016) menunjukkan adanya korelasi antara regulasi diri dan prokrastinasi akademik. Berdasarkan penjelasan yang telah dipaparkan sebelumnya, maka hipotesis yang dapat dikembangkan di dalam penelitian ini adalah dukungan sosial orang tua dan regulasi diri dapat menjelaskan terjadinya prokrastinasi akademik pada siswa SMK Farmasi Depok. 


\author{
Dela Atfilah \\ Psyche 165 Journal Vol 14 No 1 (2021) 1 - 7
}

\title{
Metode Penelitian
}

Populasi dalam penelitian ini adalah siswa SMK Farmasi Depok. Jumlah subjek yang digunakan dalam penelitian ini sebanyak 80 siswa. Pengambilan sampel menggunakan teknik sampling jenuh yaitu teknik penentuan sampel bila semua anggota populasi digunakan sebagai sampel yang diantaranya terdiri dari 20 siswa laki-laki dan 60 siswa perempuan dengan rentang usia 16-18 tahun.

Fauziyah (2016) mengatakan bahwa dukungan sosial orang tua merupakan kenyamanan secara fisik dan psikologis yang diterima anak dari orang tua. Pada penelitian ini skala dukungan sosial orang tua diadaptasi dari Fauziyah (2016). Salah satu contoh aitem dalam skala ini adalah "Orang tua selalu mengingatkan saya untu belajar". Pilihan jawaban terentang 1-4 mulai dari sangat setuju hingga sangat tidak setuju. Skala ini terdiri dari 28 item dengan 4 aspek yaitu dukungan emosional (empati, perhatian, kepedulian); dukungan penghargaan (penghargaan positif dan persetujuan gagasan); dukungan instrumental (barang/uang dan tindakan), serta dukungan informatif (nasehat dan saran). Skala dalam penelitian ini memiliki reliabilitas sebesar 0.851 .

Rizqiyah (2016) regulasi diri adalah salah satu bentuk kemampuan individu dalam hal bagaimana cara mengontrol perilaku diri sendiri. Pada penelitian ini skala regulasi diri diadaptasi dari Rizqiyah (2016). Salah satu contoh aitem dalam skala tersebut adalah "Ketika malam, saya habiskan waktu untuk menonton tv dan/atau bermain HP, daripada menyusun kembali materi pelajaran agar lebih mudah dipelajari”. Skala ini terdiri dari 40 item dan gugur sebanyak 14 item dan menjadi 26 item dengan 3 aspek yaitu metakognitif, motivasi, dan perilaku. Skala ini memiliki reliabilitas sebesar 0.856 .

Solomon \& Rothblum, 1984, Binder (2000) Khususnya dalam prokrastinasi akademik, dapat diartikan perilaku maladaptif yang hadir dan potensial pada banyak pelajar dan mahasiswa yang sering menimbulkan perasaan distres secara psikologis. Pada penelitian ini skala prokrastinasi akademik diadaptasi dari McCloskey \& Scielzo (2015). Salah satu contoh aitem dalam skala tersebut adalah "saya cenderung menunda mengerjakan sesuatu sampai hari berikutnya". Skala ini terdiri dari 25 item dengan 6 faktor yaitu psychological beliefs regarding abilities, distractions, social factors, time management, personal initiative, laziness. Skala ini memiliki reliabilitas sebesar 0.94. Teknik analisis yang digunakan dalam uji ketiga hipotesis pada penelitian ini adalah analisis regresi berganda.

\section{Hasil dan Pembahasan}

Berdasarkan tujuan dari penelitian ini, berikut akan disajikan hasil penelitian yang meliputi pengaruh dukungan sosial orang tua dan regulasi diri terhadap prokrastinasi akademik pada siswa SMK Farmasi Depok. Diperoleh hasil uji normalitas menggunakan kolmogorov-smirnov diketahui bahwa nilai $\mathrm{p}$ atau signifikansi variabel dukungan sosial orang tua sebesar 0.462; regulasi diri sebesar 0.671; dan prokrastinasi akademik sebesar 0.732. Sehingga, dapat dikatakan bahwa distribusi variabel dukungan sosial orang tua, regulasi diri, dan prokrastinasi akademik termasuk data normal karena memiliki nilai $\mathrm{p}$ atau signifikansi $>0.05$. Hasil uji linieritas ketiga variabel menunjukkan bahwa nilai signifikansi antara variabel dukungan sosial orang tua dan prokrastinasi akademik ialah sebesar 0.093. Sedangkan nilai signifikansi antara variabel regulasi diri dan prokrastinasi akademik ialah sebesar 0.356 . Sehingga dapat dikatakan bahwa distribusi data dukungan sosial orang tua, regulasi diri dan prokrastinasi akademik termasuk data linier karena memiliki nilai $\mathrm{p}$ atau signifikansi $>0.05$.

Tabel hasil regresi

\begin{tabular}{llcc}
\hline \multicolumn{1}{c}{ Variabel } & R Square & F & Sig. \\
\hline Dukungan sosial orang tua (X1) & & & \\
Regulasi Diri (X2) & .481 & 35.616 & 0.000 \\
Prokrastinasi Akademik (Y) & .48 \\
\hline
\end{tabular}

Berdasarkan tabel diatas sumbangan atau kontribusi variabel bebas terhadap variabel terikat adalah sebesar (R Square) 0.481 . Artinya sebesar $48.1 \%$ menunjukkan sumbangan atau kontribusi yang diberikan variabel dukungan sosial orang tua, regulasi diri, kepada prokrastinasi akademik dan sisanya sebesar $51.9 \%$ disebabkan oleh variabel lain diluar penelitian. Dilihat dari uji $\mathrm{F}$ sebesar 35.616 dengan signifikansi 0.000 maka secara bersama-sama dukungan sosial orang tua dan regulasi diri mempengaruhi variabel prokrastinasi akademik karena signifikansi $0.000(<0.05)$. 


\begin{tabular}{|c|c|c|c|c|c|}
\hline Model & $\begin{array}{l}\text { Unstandardized } \\
\text { Coefficients }\end{array}$ & & $\begin{array}{l}\text { Standardized } \\
\text { Coefficients }\end{array}$ & $\mathrm{t}$ & Sig. \\
\hline & $\mathrm{B}$ & Std. Error & & & \\
\hline (Constant) & 91.945 & 7.360 & & 12.493 & .000 \\
\hline $\begin{array}{l}\text { Dukungan sosial orang } \\
\text { tua }\end{array}$ & -.261 & .129 & -.173 & -2.026 & .046 \\
\hline Regulasi diri & -.856 & .116 & -.627 & -7.357 & .000 \\
\hline
\end{tabular}

Berdasarkan tabel tersebut diketahui bahwa nilai signifikansi variabel dukungan sosial orang tua sebesar $0.046(<0.05)$ menunjukkan bahwa dukungan sosial orang tua memiliki pengaruh yang signifikan dengan prokrastinasi akademik. Dengan demikian hipotesis alternatif $\left(\mathrm{H}_{\mathrm{a}}\right)$ yang diajukan diterima artinya dukungan sosial orang tua berhubungan dengan prokrastinasi akademik. Dan nilai signifikansi variabel regulasi diri sebesar $0.000(<0.05)$ menunjukkan bahwa regulasi diri memiliki hubungan yang signifikan dengan prokrastinasi akademik. Dengan demikian hipotesis alternatif $\left(\mathrm{H}_{\mathrm{a}}\right)$ yang diajukan diterima artinya regulasi diri berhubungan dengan prokrastinasi akademik memiliki hubungan yang signifikansi.

Berdasarkan tabel diatas diketahui bahwa variabel regulasi diri (X2) paling berpengaruh dibandingkan variabel dukungan sosial orang tua (X1) terhadap variabel prokrastinasi akademik (Y) dengan signifikasi sebesar 0.000 .

Pengaruh dukungan sosial orang tua terhadap prokrastinasi akademik memiliki nilai koefisien regresi sebesar -.173 . Tanda minus menyatakan arah hubungan yang tidak searah, dimana kenaikan variabel bebas $(\mathrm{X})$ mengakibatkan penurunan variabel terikat $(\mathrm{Y})$, begitu pula sebaliknya sehingga jika dukungan sosial orang tua turun satu tingkatan maka prokrastinasi akademik akan mengalami kenaikan sebesar $17.3 \%$. Begitu pula sebaliknya, apabila dukungan sosial orang tua naik satu tingkatan maka prokrastinasi akademik mengalami penurunan sebesar $17.3 \%$.

Pengaruh antara regulasi diri dan prokrastinasi akademik memiliki nilai koefisien regresi sebesar 0.627. Tanda minus menyatakan arah hubungan yang tidak searah, dimana kenaikan variabel bebas (X) mengakibatkan penurunan variabel terikat (Y), begitu pula sebaliknya sehingga jika regulasi diri turun satu tingkatan maka prokrastinasi akademik akan mengalami kenaikan sebesar $62.7 \%$. Begitu pula sebaliknya, apabila regulasi diri naik satu tingkatan maka prokrastinasi akademik mengalami penurunan sebesar $62.7 \%$.

Penelitian ini bertujuan untuk mengetahui hubungan antara dukungan sosial orang tua dan regulasi diri dengan prokrastinasi akademik pada siswa SMK Farmasi Depok.

Berdasarkan hasil penelitian ini menunjukkan terdapat hubungan yang signifikan antara dukungan sosial orang tua dan regulasi diri terhadap prokrastinasi akademik dengan $F=35.616, \mathrm{R}^{2}=0.481$, dan signifikansi $=0.000$. Kontribusi kedua variabel bebas yakni dukungan sosial orang tua dan regulasi diri terhadap variabel terikat yakni prokrastinasi akademik diketahui sebesar $R^{2}=0.481$, hal ini menunjukkan bahwa variabel dukungan sosial orang tua dan regulasi diri memberi sumbangan efektif sebesar 48.1 persen terhadap variabel prokrastinasi akademik. Hal ini membuktikan bahwa variabel dukungan sosial dan regulasi diri dapat dijadikan prediktor untuk memprediksi atau mengukur prokrastinasi. Sisanya 51.9 persen mengindikasikan adanya faktor-faktor lain yang mempengaruhi prokrastinasi akademik.

Berdasarkan uji analisis data yang telah dilakukan dengan menggunakan uji-t dalam teknik analisi regresi linier berganda diketahui bahwa dukungan sosial orang tua berhubungan secara signifikan dan negatif dengan prokrastinasi akademik yang dapat dilihat dari nilai $\mathrm{p}$ signifikansi sebesar 0.046 $(<0.05)$. Arah hubungan bersifat negatif dengan koefisien regresi sebesar -0.173 . Sehingga hipotesis pertama yang menyatakan "terdapat hubungan antara dukungan sosial orang tua dengan prokrastinasi akademik", diterima. Hubungan antara dukungan sosial orang tua dengan prokrastinasi akademik yang bernilai -0.173 menunjukkan arah hubungan yang negatif, artinya sebesar $17.3 \%$ dari variasi prokrastinasi akademik dapat diprediksikan dengan dukungan sosial orang tua. Arah hubungan yang negatif berarti bahwa semakin tinggi dukungan sosial orang tua maka semakin rendah prokrastinasi akademik. Begitu pula sebaliknya semakin rendah dukungan sosial orang tua maka semakin tinggi tingkat prokrastinasi akademiknya. 
Hal ini sejalan dengan penelitian yang dilakukan oleh Eggens dkk (2007) menemukan bahwa dukungan emosional yang diberikan oleh orangtua memiliki hubungan yang negatif yang signifikan dengan prokrastinasi. Hasil penelitian lain (Kors \& Linden, 1995) menyatakan bahwa dukungan sosial dapat mengurangi tekanan akibat aktivitas yang menimbulkan stres pada pelajar. Ketika mahasiswa/siswa mengalami stress, dukungan dari orangtua akan mengembangkan "buffers" yang berguna untuk menghadapi stres. Hasil penelitian (Kors, Linden, Lepore, Allens dan Evans, dalam Sarafino, 2006) menyatakan bahwa dukungan sosial dapat mengurangi tekanan akibat aktivitas yang menimbulkan stres pada mahasiswa/siswa. Ketika mahasiswa/siswa mengalami stres, dukungan sosial terutama dari orangtua akan mengembangkan penyangga yang berguna untuk menghadapi stres.

Hipotesis kedua yang menyatakan "terdapat hubungan antara regulasi diri dengan prokrastinasi akademik", juga diterima. Berdasarkan uji analisis data yang telah dilakukan dengan menggunakan uji-t dalam teknik analisi regresi linier berganda diketahui bahwa regulasi diri berhubungan secara signifikan yang negatif dengan prokrastinasi akademik yang dapat dilihat dari nilai $\mathrm{p}$ signifikansi sebesar $0.000(<0.05)$ dengan koefisien regresi sebesar -0.627. Hubungan antara dukungan sosial orang tua dengan prokrastinasi akademik yang bernilai -0.627. menunjukkan arah hubungan yang negatif, artinya sebesar $62.7 \%$ dari variasi prokrastinasi akademik dapat diprediksikan dengan regulasi diri. Arah hubungan yang negatif berarti bahwa semakin rendah regulasi diri maka semakin tinggi prokrastinasi akademik. Begitu pula sebaliknya semakin tinggi regulasi diri maka semakin rendah tingkat prokrastinasi akademiknya. Hal ini sejalan dengan penelitian Lukmawati dan Fitriya (2016) yang menunjukkan ada hubungan negatif yang sangat signifikan antara regulasi diri dengan perilaku prokrastinasi akademik pada mahasiswa Prodi DIII Keperawatan Sekolah Tinggi Ilmu Kesehatan (STIKES) Mitra Adiguna Palembang.

Wawancara yang dilakukan peneliti menemukan hasil bahwa siswa tidak memliki semangat untuk mengerjakan tugas, bahkan lebih banyak melakukan hal lain yang lebih menyenangkan dari pada mengerjakan tugas, seperti bermain game atau gadget, jalan-jalan, atau hanya sekedar nongkrong dengan teman-temannya. Dari wawancara tersebut terlihat bahwa siswa tidak mempunyai kemampuan untuk mengontrol dirinya sendiri.

Horward \& Miriam mengungkapkan bahwa regulasi diri adalah proses di mana seseorang dapat mengatur pencapaian dan aksi mereka sendiri. Menentukan target untuk diri mereka, mengevaluasi kesuksesan mereka saat mencapai target tersebut dan memberikan penghargaan pada diri mereka sendiri karena telah mencapai tujuan tersebut (Horward S. Friedman \& Miriam W. Schustack, 2008). Hal ini sejalan dengan penelitian Muhid (dalam Aini dan Mahardayani, 2011) yang menyatakan bahwa terdapat aspek - aspek pada diri individu yang mempengaruhi seseorang untuk mempunyai suatu kecenderungan perilaku prokrastinasi, salah satunya adalah karena rendahnya regulasi diri. Zimmerman (dalam Hendrianur, 2015) menjelaskan bahwa seseorang disebut memiliki regulasi diri jika pikiran dan perilakunya berada di bawah kendalinya sendiri, tidak dikendalikan oleh orang lain dan lingkungan. Lingkungan yang dimaksud merupakan lingkungan yang tidak baik yang dapat menghambat penyelesaian skripsi. Namun berbeda jika lingkungan tersebut kondusif. Lingkungan yang kondusif dapat mengembangkan kemampuan regulasi diri suatu individu (Susanto, 2006).

Menurut Zimmerman (dalam Hendrianur, 2015), regulasi diri seseorang dapat dilihat dari beberapa aspek yang meliputi aspek metakognitif, motivasi, dan perilaku. Dari ketiga aspek regulasi diri di atas, salah satu aspek yang sangat dominan berpengaruh terhadap munculnya kecenderungan prokrastinasi akademik adalah rendahnya pengendalian seseorang terhadap perilakunya, contohnya kurangnya kemampuan seseorang tersebut dalam memanfaatkan waktu dengan sebaik-baiknya dalam rangka menyelesaikan suatu tugas dan lebih memilih mempergunakannya untuk melakukan hal-hal yang lebih menyenangkan seperti menonton televisi, bermain game, dan lain sebagainya.

Sebagai akibat dari pengendalian yang rendah terhadap perilaku tersebut akan menyebabkan seseorang menunda untuk memulai atau menyelesaikan tugas yang seharusnya dapat diselesaikan dengan segera. Sebaliknya, seorang siswa yang memiliki perilaku yang baik akan mampu menyelesaikan tugas-tugas akademiknya dengan sesegera mungkin secara baik dan maksimal tanpa menunda-menunda untuk menyelesaikannya, sehingga dapat diasumsikan bahwa tingkat prokrastinasi seseorang tersebut terhadap berbagai tugas akademik adalah rendah. Dengan adanya kerjasama antara regulasi diri yang tinggi disertai dengan tingkat prokrastinasi (penundaan) yang rendah terhadap suatu tugas maka akan menghasilkan peningkatan yang baik terhadap proses pelaksanaan proses belajar bagi seorang siswa. 


\author{
Dela Atfilah \\ Psyche 165 Journal Vol 14 No 1 (2021) 1 - 7
}

Jika seorang individu memiliki regulasi diri yang baik, maka individu tersebut akan mampu untuk mengerahkan perhatian, fikiran, emosi dan tindakan ke tujuan (Zimmerman dalam Hendrianur, 2015). Penelitian yang dilakukan oleh Ottingen et Al. (2015) menyatakan bahwa regulasi diri yang efektif yang dapat digunakan dalam rangka memperbaiki manajemen waktu dan akan meningkatkan peningkatan fungsi hidup sehari-hari dan pengembangan jangka panjang, misalnya perubahan perilaku atau sikap pada domain akademik. Gollwitzer (2010) mengatakan bahwa prokrastinasi dapat diatasi dengan memulai perencanaan dan mengimplementasikannya melalui regulasi diri. Regulasi diri yang baik akan menghasilkan perilaku dan sikap yang berorientasi pada tujuan, memiliki komitmen dalam mengejar tujuan dan mengimplementasikan tindakan dan efikasi diri. Regulasi diri juga akan membantu individu dalam mengontrol diri.

Hipotesis ketiga yang menyatakan "terdapat hubungan antara dukungan sosial orang tua dan regulasi diri dengan prokrastinasi akademik", diterima. Ini terlihat dari signifikani yaitu sebesar 0.000 ( $\mathrm{p}<0.05)$. Hal ini sejalan dengan penelitian Hendrianur (2015), dimana dengan memiliki dukungan sosial yang tinggi serta dapat meregulasi diri, siswa dapat menyelesaikan tugas bahkan sebelum batas waktu yang ditentukan.

\title{
Kesimpulan
}

Berdasarkan hasil penelitian yang dilakukan di SMK Farmasi Depok, dapat disimpulkan bahwa dukungan sosial memiliki pengaruh terhadap prokrastinasi akademik Tanda minus menyatakan arah hubungan yang tidak searah. Artinya semakin tinggi dukungan sosial orang tua maka semakin rendah prokrastinasi akademik. Begitu pula sebaliknya, semakin rendah dukungan sosial orang tua maka semakin tinggi prokrastinasi akademik.

Regulasi diri dengan prokrastinasi akademik juga terdapat pengaruh yang signifikan. Tanda minus menyatakan arah hubungan yang tidak searah. Artinya semakin tinggi regulasi diri maka semakin rendah prokrastinasi akademik. Begitu pula sebaliknya, semakin rendah regulasi diri maka semakin tinggi prokrastinasi akademik.

Nilai signifikansi sebesar 0.000 berarti dukungan sosial orang tua dan regulasi diri secara bersamasama memiliki hubungan yang signifikan dengan prokrastinasi akademik.

\section{Saran}

Bagi peneliti selanjutnya disarankan agar mencari faktor-faktor lain yang mendukung prokrastinasi akademik selain faktor-faktor yang diteliti oleh peneliti.

\section{Daftar Pustaka}

(1) Aini, A.N \& Mahardayani, I.H. (2011). Hubungan Antara Kontrol Diri Dengan Prokrastinasi Dalam Menyelesaikan Skripsi Pada Mahasiswa Universitas Muria Kudus. Jurnal Psikologi Pitutur, 1(2) 65-71

(2) Ardina, Putri Ramadhani Ayu \& Wulan, Dwi Kencana. (2016). Pengaruh Regulasi Diri Terhadap Prokrastinasi Akademik Pada Siswa SMA. Perspektif Ilmu Pendidikan. 30 (2)

(3) Balkis, M. (2013). "Academic Procrastination, Academic Life Satisfaction And Academic Achievement: The Mediation Role Of Rational Beliefs About Studying." Journal of Cognitive and Behavioral Psychotherapies, 13(1) 57-74.

(4) Corville-Smith, J., Ryan, B.A., Adams, G., \& Dalicandro, T. (1998). Distinguishing absentee students from regular attenders: The combined influence of personal, family, and school factors. Journal of Youth and Adolescence.

(5) Fitriya \& Lukmawati. (2016). "Hubungan Antara Regulasi Diri Dengan Perilaku Prokrastinasi Akademik Pada Mahasiswa Sekolah Tinggi Ilmu Kesehatan (Stikes) Mitra Adiguna Palembang”. Jurnal Psikologi Islami. 2 (1)

(6) Hendrianur. (2015). Hubungan Dukungan Sosial dan Regulasi Diri dengan Prokrastinasi dalam Menyelesaikan Skripsi. eJournal Psikologi.

(7) Hurlock, Elisabeth B. (1980). Psikologi Perkembangan. Jakarta: Penerbit Erlangga

(8) Lee,S, \& Detels, R. (2007). The effects of social support on mental and behavioral outcomers among adolescents with parents with HIV/AIDS. Journal of Public Health. United States.

(9) Mappiare, Andi. (1982). Psikologi Remaja. Surabaya: Usaha Nasional

(10) McCloskey, J. (2011). Academic procrastination. Thesis. University of Texas. 


\section{Dela Atfilah \\ Psyche 165 Journal Vol 14 No 1 (2021) 1 - 7}

(11) Muhid, A. (2009). "Hubungan antara selfcontrol dan self-Efficacy dengan kecenderungan perilaku prokrastinasi akademik mahasiswa." Journal

(12) Musyarofah, Siti. (2017). "Hubungan Kedisiplinan Siswa dengan Prokrastinasi Akademik Siswa Kelas XI SMK Piri 1 Yogyakarta”. Skripsi: Fakultas Dakwah dan Komunikasi Psikologi Universitas Islam Negeri Sunan Kalijaga.

(13) Puspitasari, Devi Brantaningtyas. (2012). "Hubungan Antara Persepsi Terhadap Iklim Kelas dengan Motivasi Belajar Siswa SMP Negeri 1 Bacak". Jurnal Psikologi. 1(1)

(14) Pychyl, T. A., Lee, J. M., Thibodeau, R., \& Blunt, A. (2000). Five days of emotion: An experience sampling study of undergraduate student procrastination. Journal of Social Behavior and Personality, (15).

(15) Saraswati, Putri. (2017). "Strategi Self Regulated Learning dan Prokrastinasi Akademik Terhadap Prestasi Akademik.” Journal

(16) Solomon, L. J., \& Rothblum, E. D. (1984). Academic procrastination: Frequency and cognitivebehavioral correlates. Journal of Counseling Psychology, 31(4), 503-509.

(17) Steel, P. (2007). The nature of procrastination: A metaanalytic and theoretical review of quintessential self-regulatory failure. Psychological Bulletin, 133, 65-94.

(18) Susanto, H. 2006. Mengembangkan Kemampuan Self Regulation untuk Meningkatkan Keberhasilan Akademik Siswa. Jurnal Pendidikan Penabur.

(19) Tarmidi, \& Rambe, Ade Riza Rahma. (2010). “Korelasi Antara Dukungan Sosial Orang Tua dan Self-Directed Learning pada Siswa SMA”. Jurnal Psikologi. 37(2). 